\title{
Pre-SVF arthroscopy: A case report of new concept of meniscus and cartilage regeneration using arthroscopy followed by intra-articular injection of adipose-derived stromal vascular fraction
}

\author{
Nizar Al-Salahat \\ *Correspondence: dr.nizar@stemcell4joints.com

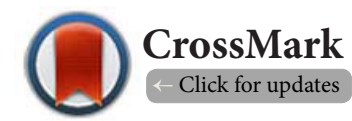

Stem Cell 4 Joints. \#15 Suleiman Hadidi St. Amman, Jordan.

\begin{abstract}
Background: A series of clinical case reports demonstrating the intra-articular injection of autologous adipose-derived stem cells (The Stromal Vascular Fraction - SVF) combined with platelet rich plasma (PRP), hyaluronic acid, and calcium chloride after arthroscopy procedure (Pre-SVF Arthroscopy) has a therapeutic potential to regenerate cartilage in knee osteoarthritis for elderly patient and athletes with meniscus tears as well as preventing re-tears occurrence.
\end{abstract}

Case presentation: A study of three patients underwent arthroscopy procedure for unilateral knee followed by stem cells intra-articular injection that were obtained from abdominal adipose tissue by digesting lipoaspirate tissue with collagenase. The adipose-derived stem cells (Stromal Vascular Fraction - SVF) were injected into the patients knee along with hyaluronic acid, platelet rich plasma and calcium chloride after the arthroscopy procedure. All patients had an injury of medial or/and lateral meniscus, osteoarthritis, history of pain and limitation of motion. Pre-treatment and post-treatment MRI scans, modified functional rate index and pain score data were then analyzed.

Conclusion: Some patients may suffer from meniscus injury with symptoms such as locked knee, which may not benefit significantly with SVF intra-articular injection solely. The Pre-SVF arthroscopy procedure has shown to solve the mechanical related symptoms of the knee movement and to regenerate damage tissues, without complication or risk of early onset osteoarthritis. This clinical study conducted three patients underwent Pre-SVF arthroscopy which gain significant clinical improvement and MRI evidence of meniscus and articular cartilage regeneration.

Keywords: Adipose derived stem cell, meniscus tear, knee osteoarthritis, Pre-SVF arthroscopy, autologous mesenchymal stem cell, case report

\section{Background}

The menisci are two semilunar, fibro-cartilaginous discs located between the medial and lateral articular surfaces of the femur and tibia which have a key function of (i) transfer of weight, (ii) absorb shocks, and (iii) cartilage protection [1]. The meniscus injury can be diagnosed with clinical examination and confirmed by MRI scans [2]. The pain caused by meniscus injury is initially treated conservatively $[3,4]$. If the conservative treatment fails, a meniscectomy is considered. However, the meniscectomy treatment -or even partial one- is associated with early onset of osteoarthritis of the knee [5-8]. Further, The New England Journal of Medicine published a series of controlled clinical trials showing limited effects of arthroscopic surgery for the treatment of OA [9-12]. Common conservative treatment including physical therapy, viscosupplementation [13], glucosamine and/or chondroitin sulfate [14], and acupuncture [15] have demonstrated modest to no clinical benefit when compared with placebo. The objective of these treatments tend to decrease pain, maintain or improve joint function, and minimized disability, without regenerating the 
Nizar Al-Salahat, Stem Cell Biology and Research 2016,

joint tissue. However, the regeneration of articular cartilage and meniscus via intra-articular introduction of mesenchymal stem cells (MSCs) has been showing promising results which have a great potential as a future therapeutic agent in the field of regenerative medicine. We have seen much in vitro [16-18], in vivo [19-30], and clinical [31-43] experimentation on MSCs.

MSCs are multipotent cells that can be extracted from bone marrow and adipose tissue of abdomen, thigh and hips $[\mathbf{4 4 , 4 5 ]}$. MSCs are capable to differentiate into bone, cartilage and muscle, and represent promising therapy in regenerative medicine [31-33]. Reports of successful regeneration of bone and cartilage in humans have been demonstrated using various MSCs [32-43], particularly adipose-derived stem cells (ADSCs) [35-40]. However, there are a lack of studies on regenerative medicine via intra-articular injected MSCs of middle-age patients or athletes who has absolute indication of knee arthroscopy which been demonstrated in some studies $[46,47]$. We have seen a report study with a promising result of rotator cuff repair followed by BM-MSCs which improve healing and prevent re-tear [48]. However, there are no relevant studies on knee or hip cases (as we aware of).

\section{Case presentation}

On April 21, 2009, Guideline for transplantation and treatment with tissue engineering (TE) techniques was issued by the Ministry of Health of P.R. China [49]. Here, we present case study report on a successful clinical results using intra-articular injected autologous ASCs along with platelet-rich plasma (PRP), hyaluronic acid and $\mathrm{CaCl} 2$ following the arthroscopy procedure.

The inclusion criteria, exclusion criteria, and endpoints of the outcome are listed in Tables 1-3 [40].

\section{Patients history}

\section{Patient 1}

The patient is a 47-year-old male athletes presented with left knee pain and limitation of movement due to past injury, he

Table 1. Including criteria.

\begin{tabular}{l}
\hline Description \\
\hline 1. MRI evidence of meniscus tear. \\
2. Absolute indication for arthroscopy \\
(i.e., Locked knee, mechanical LOM due to osteophytes. \\
3. Willing to proceed with arthroscopic partial meniscectomy. \\
4. Failure of conservative treatment. \\
5. Continuous pain.
\end{tabular}

Table 2. Exclusion criteria.

\begin{tabular}{l}
\hline Description \\
\hline 1. Active inflammatory or connective tissue disease (i.e. lupus, RA). \\
2. Active neurologic disorder \\
(i.e. peripheral neuropathy, multiple sclerosis). \\
3. Severe cardiac disease.
\end{tabular}

Table 3. Outcome data collection.

\begin{tabular}{l}
\hline Description \\
\hline Pre and post treatment visual analog scale (VAS). \\
Pre and post treatment functional rating index (FRI). \\
Pre and post treatment range of motion. \\
Pre and post treatment MRI.
\end{tabular}

had a daily pain score $4 / 10$ increased to $7 / 10$ with walking. On physical examination, there was medial joint tenderness and positive patellar grind test. Apley's and McMurray tests were positive, and no joint swelling, range of motion as in Table 4. Pre-treatment left knee MRI demonstrated grad I-II damage of patellar cartilage, grade III damage of posterior horn lateral meniscus, grade I damage of $\mathrm{ACL}$, and mild degenerative changes.

Table 4. Functional Rating Index (FRI) and Visual Analog Score (VAS) walking index.

\begin{tabular}{lllll}
\hline Patients & $\begin{array}{l}\text { Outcome } \\
\text { measures }\end{array}$ & Pre-treatment & $\begin{array}{l}\text { 3 Months } \\
\text { post }\end{array}$ & $\begin{array}{l}\text { 9 Months } \\
\text { post }\end{array}$ \\
\hline Patient 1 & FRI & 10 & 0 & 0 \\
& VAS & 7 & 0 & 0 \\
& R.O.M & $0^{\circ}-140^{\circ}$ & $0^{\circ}-155^{\circ}$ & $0^{\circ}-155^{\circ}$ \\
\hline Patient 2 & FRI & 16 & 6 & 4 \\
& VAS & 8 & 5 & 0 \\
& R.O.M & $5^{\circ}-120^{\circ}$ & $0^{\circ}-135^{\circ}$ & $0^{\circ}-140^{\circ}$ \\
\hline Patient 3 & FRI & 11 & 4 & 0 \\
& VAS & 6 & 0 & 0 \\
& R.O.M & $5^{\circ}-135^{\circ}$ & $0^{\circ}-145^{\circ}$ & $0^{\circ}-145^{\circ}$ \\
\hline
\end{tabular}

\section{Patient 2}

The patient is 57-year-old male presented with right knee pain since 3 years. He had daily pain score $6 / 10$ increased to $8 / 10$ with daily activities. On physical examination, right knee McMurry test were positive with locked knee, range of motion as in Table 4. Pre-treatment MRI showed right knee medial and lateral meniscus injury with osteoarthritis changes.

\section{Patient 3}

The patient is 60-year-old male presented with left knee pain since 5 months, he had history of left knee trauma since he was 20 -year-old. He had a daily pain score $4 / 10$ increased to $6 / 10$ with daily activities. On physical examination, left knee McMurry test was positive with locked knee, range of motion as in Table 4. Pre-treatment MRI showed left knee medial meniscus injury, patellar chondromalacia and early osteoarthritis changes.

\section{Materials and methods}

One week prior to Pre-SVF arthroscopy procedure, the patients was restricted from taking corticosteroids, NSAIDs, and aspirin. 
The patients were placed supine on OR table, a standardized protocol for general anesthesia was followed. Abdominal towel was placed after painting the abdominal area. Then, patient 1 had two incisions of approximately $0.5 \mathrm{~cm}$ were made approximately $15 \mathrm{~cm}$ on right and left sides of the umbilicus, while patient 2 and patient 3 had one incision of approximately $0.5 \mathrm{~cm}$ were made $3 \mathrm{~cm}$ infra-umbilicus. tumescent solution was injected $\left(1000 \mathrm{~cm}^{3}\right.$ normal saline, 10 $\mathrm{cm}^{3}$ ropivacaine, $20 \mathrm{~cm}^{3}$ lidocaine, $0.5 \mathrm{~cm}^{3}$ epinephrine). Then using 3.5 cannula extracting a total of $450 \mathrm{~cm}^{3}$ of lipoaspirate, which resulted in total of $250 \mathrm{~cm}^{3}$ adipose tissue separated by gravity. The adipose tissue was sent for processing, and arthroscopy procedure began.

\section{Arthroscopy}

The arthroscopic surgery was performed, medial and lateral meniscus was explored interiorly, partially excised and smoothened in a special technique to keep the structure of the meniscus, which aim to minimally trimming of the inferior part of the injured area of the meniscus, maintaining the scaffold and the shape of the meniscus. The intra-articular tube was then applied, incision is sutured, crepe bandage was applied. The adipose derived stem cell mixture was then injected via tube, and then tube is removed. Hinged knee support was applied.

\section{ADSC processing}

The resulting $250 \mathrm{~cm}^{3}$ of adipose tissue was centrifuged at 700 RCF for 5 minutes. Which result approximately $180 \mathrm{~cm}^{3}$ of packed adipose tissue, fibrous tissue, red blood cells, and small amount of nucleated cells. Then, ADCs were extracted by the use of digestive enzymes, collagenase type I derived from Clostridium histolyticum (SERVA; Heidelberg, Germany), and mixed with the centrifuged lipoaspirate at ratio of 1:1 and digested for 30 minutes at $37^{\circ} \mathrm{C}$ while rotating [45]. After digestion, the lipoaspirate was separated of the enzyme by centrifugation at 800 RCF for 5 minutes, the separated enzyme was then removed. The lipoaspirate were then washed 3 times to remove the collagenase, and the lipoaspirate were centrifuged at 800 RCF after each wash. Finally, approximately 6 $\mathrm{cm}^{3}$ of ADSCs were obtained after the last centrifuge process.

While preparing the ADSCs, $49 \mathrm{~cm}^{3}$ of autologous blood was drawn with $14 \mathrm{~cm}^{3}$ of anticoagulant mixture (ACD-A), then centrifuged at 1700 RCF for 5 minutes. Then, the supernatant was drawn and discarded. Obtained is $4 \mathrm{~cm}^{3}$ PRP. The PRP was activated by mixed with $\mathrm{CaCl} 2$ at a ratio of 10:1 (PRP 10:1 $\mathrm{CaCl} 2$ ). Hyaluronic acid $3 \mathrm{~cm}^{3}$ was added to act as a scaffold.

After obtaining the ADSCs mixture and PRP, the mixture was injected via the intra-articular tube, and then tube was removed, the patient referred from recovery room to the ward. After discharged, the patient was told to maintain activity as tolerated.

The patient returned in the days 3, 7, 14 of the first procedure for additional three PRP injections and one HA injection.

\section{Result}

The patients had follow-up after the treatment in six months and nine months, their symptoms have significantly improved, modified functional rating index and visual analog score walking index $[\mathbf{5 0 , 5 1}]$ showed in Table 4 . While follow-up, the patients were observed if symptoms improvement persistent, develop any complications (e.g., illness, infection), and if developed any form of cancer since the procedure. The patient did not report any of these complications or serious side effects, a recent report supports this result [30]. Repeated MRI after $6 \sim 9$ months showed significant regeneration of the torn meniscus, and thickness in the articular cartilage (Figures 1-3).

It is estimated that approximately 400,000 ADSCs are obtained in one gram of adipose tissue [52]. And since 180 grams of centrifuged adipose tissue were obtained, it is believed that approximately 72 million adipose derived stem cells were injected into the patient's knee.

\section{Discussion}

This clinical case report provides MRI evidence before and after ADSCs treatment, the significant signal changes can be interpreted as sign of restored and regenerated meniscus. MRI results can be compared with sequential views to compensate any possible errors. The findings of the present study demonstrates that adipose-derived stem cell is effective in cartilage healing, reducing pain, and improving joint func-
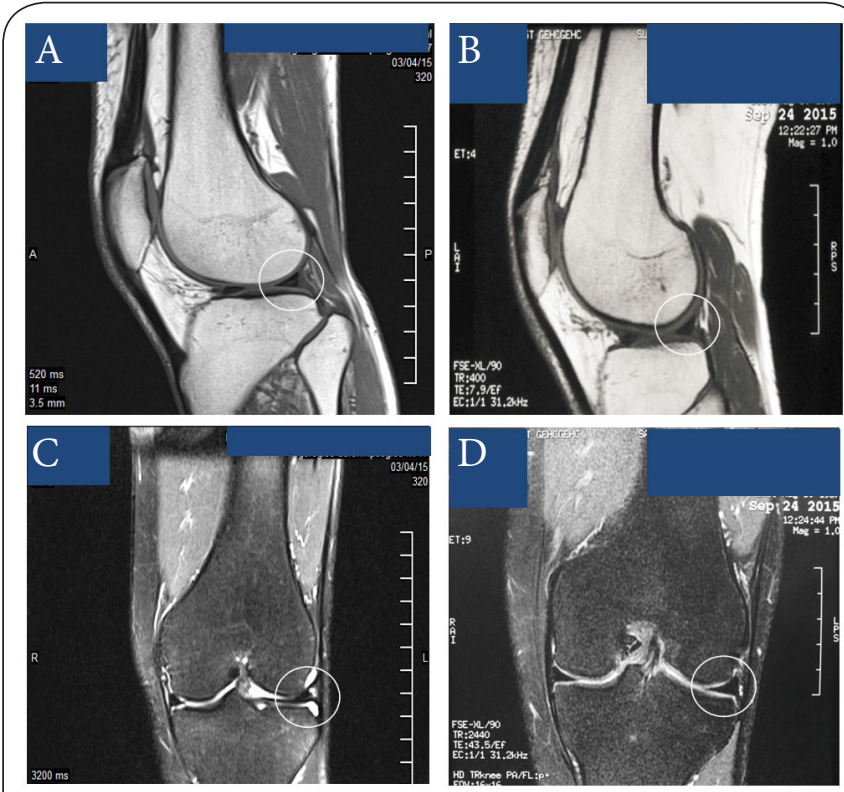

Figure 1. Patient 1 MRI sagittal and coronal views of the left knee. Pre-treatment MRI scan demonstrate a tear within the posterior horn lateral meniscus in sagittal view (A) and coronal view (B). Post-treatment MRI scan at 6 months demonstrate the healed meniscus, increased thickness of articular cartilage, as well as improved quality of the articular cartilage in sagittal view (C) and coronal view (D) which been regenerated and repaired by the Pre-SVF arthroscopy treatment. 


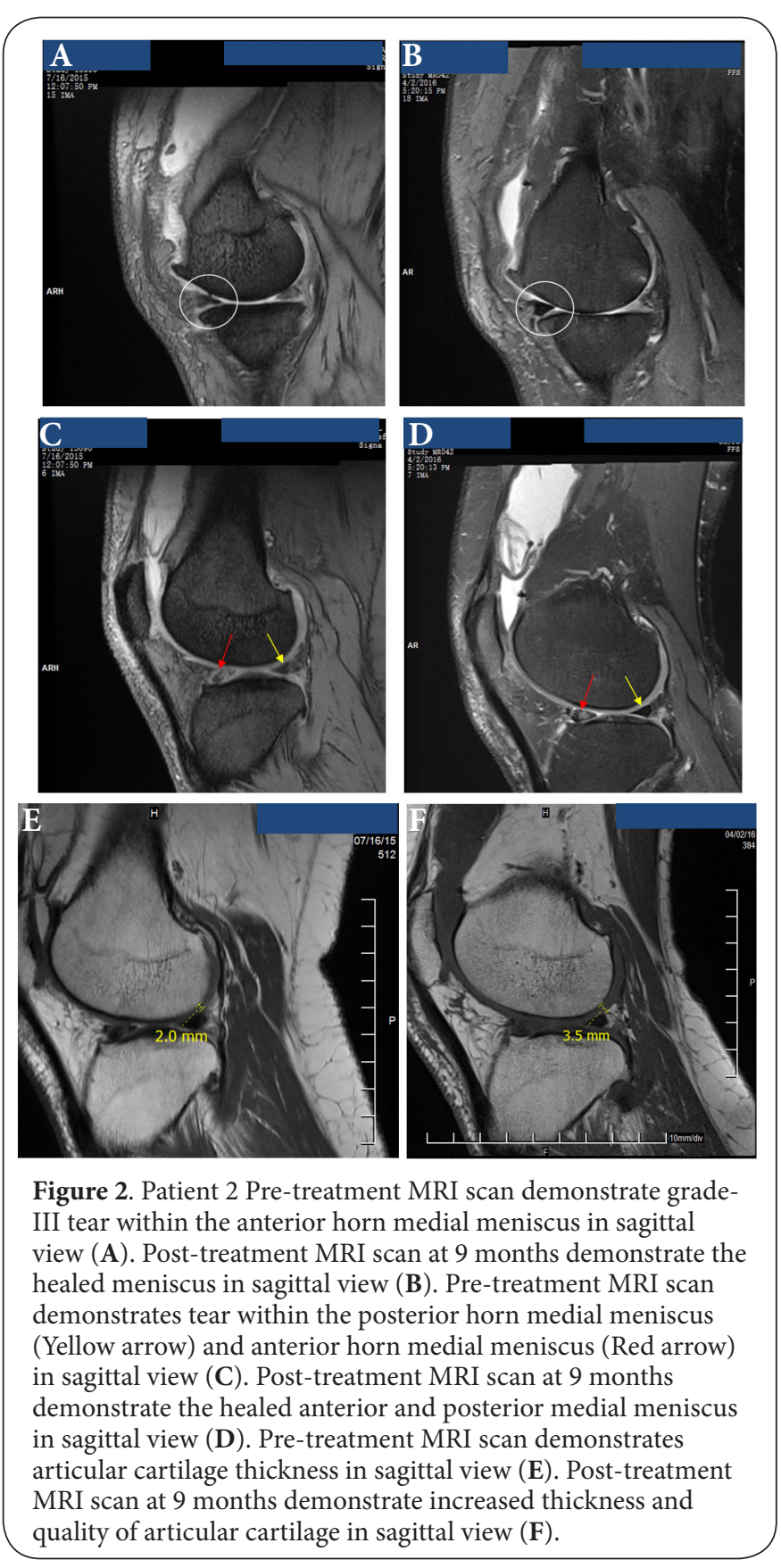

tion of patients with meniscus tear and knee OA. However, there is no way to determine the nature of the regenerated tissue without biopsy. Longer term follow up of this patient will continue.

There are few possible mechanisms of the regenerative meniscal and cartilage: (i) direct differentiation of ADSCs [45,53-74]; (ii) paracrine effects of ADSCs on the existing tissue [75-91]; (iii) the growth factors contained in PRP [92-99], which also may stimulate the injected stem cells to proliferate and differentiate [100,101]; Or (iv) combination of previously mentioned possibilities. According to this clinical study, and
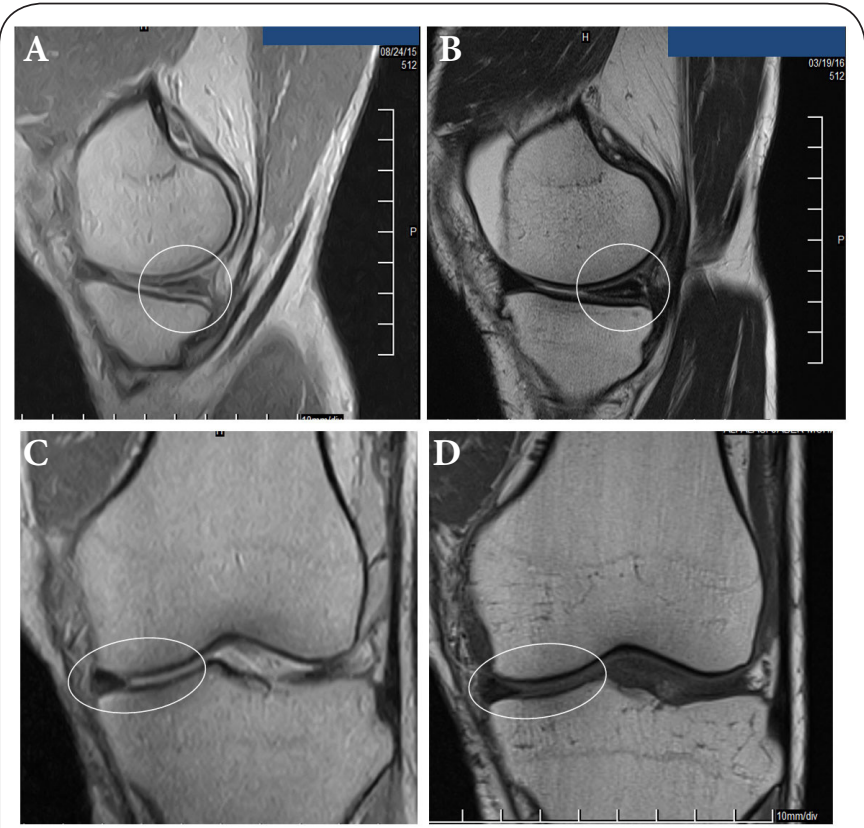

Figure 3. Patient 3 Pre-treatment MRI scan demonstrate gradeIII tear within the posterior horn medial meniscus in sagittal view (A). Post-treatment MRI scan at 6 months demonstrate the healed meniscus in sagittal view (B). Pre-treatment MRI scan demonstrates degenerative changes within the medial meniscus body coronal view (C). Post-treatment MRI scan at 6 months demonstrate regenerative changes within the medial meniscus body and articular cartilage in coronal view (D).

previous clinical reports [32-37,40,102], it is found that ADSCs mixture-based treatment play an important role in repair the cartilage and torn meniscus.

The limitation of the present study that there is no control group was included, in order to measure the effectiveness and compare results of patients that have similar symptoms and absolute indication of arthroscopy, future studies will compare these patients results with Pre-SVF arthroscopy treatment (for the group of patients who are willing to proceed with arthroscopy) and control group (SVF without arthroscopy for patients who are unwilling to proceed with arthroscopy, or arthroscopy without SVF for patients who are unwilling to proceed with SVF).

\section{Competing interests}

The author declares that he has no competing interests.

\section{Acknowledgement}

The author acknowledges the staff of Beijing Puhua International Hospital and cell lab specialists for support. Clinical trial and publishing consents are obtained from all patients.

\section{Publication history}

EIC: Prasad S Koka, Haffkine Institute for Training, Research \& Testing, India.

Received: 02-Jul-2016 Final Revised: 01-Aug-2016

Accepted: 08-Aug-2016 Published: 19-Aug-2016 
Nizar Al-Salahat, Stem Cell Biology and Research 2016,

http://www.hoajonline.com/journals/pdf/2054-717X-3-2.pdf

\section{References}

1. Englund M, Guermazi A, Gale D, Hunter DJ, Aliabadi P, Clancy M and Felson DT. Incidental meniscal findings on knee MRI in middle-aged and elderly persons. N Engl J Med. 2008; 359:1108-15. | Article | PubMed Abstract | PubMed FullText

2. Magee T and Williams D. 3.0-T MRI of meniscal tears. AJR Am J Roentgenol. 2006; 187:371-5. | Article | PubMed

3. DeHaven KE. Decision-making factors in the treatment of meniscus lesions. Clin Orthop Relat Res. 1990; 49-54. | PubMed

4. Newman AP, Daniels AU and Burks RT. Principles and decision making in meniscal surgery. Arthroscopy. 1993; 9:33-51. | Article | PubMed

5. Jorgensen U, Sonne-Holm S, Lauridsen F and Rosenklint A. Long-term follow-up of meniscectomy in athletes. A prospective longitudinal study. J Bone Joint Surg Br. 1987; 69:80-3. | Article | PubMed

6. Roos $\mathrm{H}$, Lauren M, Adalberth T, Roos EM, Jonsson K and Lohmander LS. Knee osteoarthritis after meniscectomy: prevalence of radiographic changes after twenty-one years, compared with matched controls. Arthritis Rheum. 1998; 41:687-93. | Article | PubMed

7. Englund M, Roos EM and Lohmander LS. Impact of type of meniscal tear on radiographic and symptomatic knee osteoarthritis: a sixteenyear followup of meniscectomy with matched controls. Arthritis Rheum. 2003; 48:2178-87. | Article | PubMed

8. Petty CA and Lubowitz JH. Does arthroscopic partial meniscectomy result in knee osteoarthritis? A systematic review with a minimum of 8 years' follow-up. Arthroscopy. 2011; 27:419-24. | Article | PubMed

9. Katz JN and Losina E. Surgery versus physical therapy for meniscal tear and osteoarthritis. N Engl J Med. 2013; 369:677-8. | Article | PubMed

10. Kirkley A, Birmingham TB, Litchfield RB, Giffin JR, Willits KR, Wong CJ, Feagan BG, Donner A, Griffin SH, D'Ascanio LM, Pope JE and Fowler PJ. A randomized trial of arthroscopic surgery for osteoarthritis of the knee. N Engl J Med. 2008; 359:1097-107. | Article | PubMed

11. Sihvonen R, Paavola M, Malmivaara A, Itala A, Joukainen A, Nurmi $H$, Kalske $J$ and Jarvinen TL. Arthroscopic partial meniscectomy versus sham surgery for a degenerative meniscal tear. N Engl J Med. 2013; 369:2515-24. | Article | PubMed

12. Moseley JB, O'Malley K, Petersen NJ, Menke TJ, Brody BA, Kuykendall $\mathrm{DH}$, Hollingsworth JC, Ashton CM and Wray NP. A controlled trial of arthroscopic surgery for osteoarthritis of the knee. N Engl J Med. 2002; 347:81-8. | Article | PubMed

13. Rutjes AW, Juni P, da Costa BR, Trelle S, Nuesch E and Reichenbach S. Viscosupplementation for osteoarthritis of the knee: a systematic review and meta-analysis. Ann Intern Med. 2012; 157:180-91. | Article | PubMed Abstract | PubMed FullText

14. Sawitzke $A D$, Shi $H$, Finco MF, Dunlop DD, Harris $C L$, Singer NG, Bradley JD, Silver D, Jackson CG, Lane NE, Oddis CV, Wolfe F, Lisse J, Furst DE, Bingham CO, Reda DJ, Moskowitz RW, Williams HJ and Clegg DO. Clinical efficacy and safety of glucosamine, chondroitin sulphate, their combination, celecoxib or placebo taken to treat osteoarthritis of the knee: 2-year results from GAIT. Ann Rheum Dis. 2010; 69:1459-64. Article | PubMed Abstract | PubMed FullText

15. Witt C, Brinkhaus B, Jena S, Linde K, Streng A, Wagenpfeil S, Hummelsberger J, Walther HU, Melchart D and Willich SN. Acupuncture in patients with osteoarthritis of the knee: a randomised trial. Lancet. 2005; 366:136-43. | Article | PubMed

16. Ando W, Tateishi K, Hart DA, Katakai D, Tanaka Y, Nakata K, Hashimoto J, Fujie H, Shino K, Yoshikawa H and Nakamura N. Cartilage repair using an in vitro generated scaffold-free tissue-engineered construct derived from porcine synovial mesenchymal stem cells. Biomaterials. 2007; 28:5462-70. | Article | PubMed

17. Ando W, Tateishi K, Katakai D, Hart DA, Higuchi C, Nakata K, Hashimoto $\mathrm{J}$, Fujie $\mathrm{H}$, Shino $\mathrm{K}$, Yoshikawa $\mathrm{H}$ and Nakamura $\mathrm{N}$. In vitro generation of a scaffold-free tissue-engineered construct (TEC) derived from human synovial mesenchymal stem cells: biological and mechanical properties and further chondrogenic potential. Tissue Eng Part A. 2008; 14:2041-9. | Article | PubMed

18. Tallheden T, Dennis JE, Lennon DP, Sjogren-Jansson E, Caplan Al and Lindahl A. Phenotypic plasticity of human articular chondrocytes. $J$ Bone Joint Surg Am. 2003; 85-A Suppl 2:93-100. | Article I PubMed

19. Nevo Z, Robinson D, Horowitz S, Hasharoni A and Yayon A. The manipulated mesenchymal stem cells in regenerated skeletal tissues. Cell Transplant. 1998; 7:63-70. | Article | PubMed

20. Bielby R, Jones $E$ and McGonagle $\mathrm{D}$. The role of mesenchymal stem cells in maintenance and repair of bone. Injury. 2007; 38 Suppl 1:S2632. | Article | PubMed

21. Wakitani S, Goto T, Pineda SJ, Young RG, Mansour JM, Caplan Al and Goldberg VM. Mesenchymal cell-based repair of large, full-thickness defects of articular cartilage. J Bone Joint Surg Am. 1994; 76:579-92. Article | PubMed

22. Sakai D, Mochida J, Yamamoto $Y$, Nomura T, Okuma M, Nishimura $K$ Nakai T, Ando K and Hotta T. Transplantation of mesenchymal stem cells embedded in Atelocollagen gel to the intervertebral disc: a potential therapeutic model for disc degeneration. Biomaterials. 2003; 24:3531-41. | Article | PubMed

23. Johnstone $B$ and Yoo JU. Autologous mesenchymal progenitor cells in articular cartilage repair. Clin Orthop Relat Res. 1999; S156-62. I Article | PubMed

24. Agung M, Ochi M, Yanada S, Adachi N, Izuta Y, Yamasaki T and Toda K. Mobilization of bone marrow-derived mesenchymal stem cells into the injured tissues after intraarticular injection and their contribution to tissue regeneration. Knee Surg Sports Traumatol Arthrosc. 2006; 14:1307-14. | Article | PubMed

25. Sakai D, Mochida J, Iwashina T, Watanabe T, Nakai T, Ando K and Hotta T. Differentiation of mesenchymal stem cells transplanted to a rabbit degenerative disc model: potential and limitations for stem cell therapy in disc regeneration. Spine (Phila Pa 1976). 2005; 30:2379-87. | Article | PubMed

26. Walsh CJ, Goodman D, Caplan Al and Goldberg VM. Meniscus regeneration in a rabbit partial meniscectomy model. Tissue Eng. 1999; 5:327-37. | Article | PubMed

27. Nishimori $\mathrm{M}$, Deie $\mathrm{M}$, Kanaya $\mathrm{A}$, Exham $\mathrm{H}$, Adachi $\mathrm{N}$ and Ochi $\mathrm{M}$. Repair of chronic osteochondral defects in the rat. A bone marrowstimulating procedure enhanced by cultured allogenic bone marrow mesenchymal stromal cells. J Bone Joint Surg Br. 2006; 88:1236-44. | Article | PubMed

28. Yamasaki T, Deie $M$, Shinomiya R, Izuta $Y$, Yasunaga $Y$, Yanada $S$, Sharman $P$ and Ochi M. Meniscal regeneration using tissue engineering with a scaffold derived from a rat meniscus and mesenchymal stromal cells derived from rat bone marrow. J Biomed Mater Res A. 2005; 75:23-30. | Article | PubMed

29. Kanaya A, Deie M, Adachi N, Nishimori M, Yanada S and Ochi M. Intra-articular injection of mesenchymal stromal cells in partially torn anterior cruciate ligaments in a rat model. Arthroscopy. 2007; 23:6107. | Article | PubMed

30. Pak J, Chang JJ, Lee JH and Lee SH. Safety reporting on implantation of autologous adipose tissue-derived stem cells with platelet-rich plasma into human articular joints. BMC Musculoskelet Disord. 2013; 14:337. | Article | PubMed Abstract | PubMed FullText

31. Barry FP. Mesenchymal stem cell therapy in joint disease. Novartis Found Symp. 2003; 249:86-96. | PubMed

32. Centeno CJ, Kisiday J, Freeman M and Schultz JR. Partial regeneration of the human hip via autologous bone marrow nucleated cell transfer: A case study. Pain Physician. 2006; 9:253-6. | Article | PubMed

33. Centeno CJ, Busse D, Kisiday J, Keohan C, Freeman M and Karli D. Regeneration of meniscus cartilage in a knee treated with 
Nizar Al-Salahat, Stem Cell Biology and Research 2016,

percutaneously implanted autologous mesenchymal stem cells. Med Hypotheses. 2008; 71:900-8. | Article | PubMed

34. Giannini S, Buda R, Cavallo M, Ruffilli A, Cenacchi A, Cavallo C and Vannini $F$. Cartilage repair evolution in post-traumatic osteochondral lesions of the talus: from open field autologous chondrocyte to bonemarrow-derived cells transplantation. Injury. 2010; 41:1196-203. | Article | PubMed

35. Pak J. Autologous adipose tissue-derived stem cells induce persistent bone-like tissue in osteonecrotic femoral heads. Pain Physician. 2012 15:75-85. | Article | PubMed

36. Pak J, Lee JH and Lee SH. A novel biological approach to treat chondromalacia patellae. PLoS One. 2013; 8:e64569. | Article | PubMed Abstract | PubMed FullText

37. Kulakov AA, Goldshtein DV, Grigoryan AS, Rzhaninova AA, Alekseeva IS, Arutyunyan IV and Volkov AV. Clinical study of the efficiency of combined cell transplant on the basis of multipotent mesenchymal stromal adipose tissue cells in patients with pronounced deficit of the maxillary and mandibulary bone tissue. Bull Exp Biol Med. 2008; 146:522-5. | Article | PubMed

38. Mesimaki K, Lindroos B, Tornwall J, Mauno J, Lindqvist C, Kontio $R$, Miettinen $S$ and Suuronen R. Novel maxillary reconstruction with ectopic bone formation by GMP adipose stem cells. Int J Oral Maxillofac Surg. 2009; 38:201-9. | Article | PubMed

39. Taylor JA. Bilateral orbitozygomatic reconstruction with tissueengineered bone. J Craniofac Surg. 2010; 21:1612-4. | Article | PubMed

40. Pak J, Lee JH and Lee $\mathrm{SH}$. Regenerative repair of damaged meniscus with autologous adipose tissue-derived stem cells. Biomed Res Int. 2014; 2014:436029. | Article | PubMed Abstract | PubMed FullText

41. Kuroda R, Ishida K, Matsumoto T, Akisue T, Fujioka H, Mizuno K, Ohgushi $\mathrm{H}$, Wakitani S and Kurosaka M. Treatment of a full-thickness articular cartilage defect in the femoral condyle of an athlete with autologous bone-marrow stromal cells. Osteoarthritis Cartilage. 2007; 15:226-31. | Article | PubMed

42. Slynarski K, Deszczynski J and Karpinski J. Fresh bone marrow and periosteum transplantation for cartilage defects of the knee. Transplant Proc. 2006; 38:318-9. | Article | PubMed

43. Wakitani S, Okabe T, Horibe S, Mitsuoka T, Saito M, Koyama T, Nawata M, Tensho K, Kato H, Uematsu K, Kuroda R, Kurosaka M, Yoshiya S, Hattori K and Ohgushi H. Safety of autologous bone marrow-derived mesenchymal stem cell transplantation for cartilage repair in 41 patients with $\mathbf{4 5}$ joints followed for up to $\mathbf{1 1}$ years and $\mathbf{5}$ months. J Tissue Eng Regen Med. 2011; 5:146-50. | Article | PubMed

44. Caplan Al. Mesenchymal stem cell. J Orthop Res. 1991; 9:641-650.

45. Zuk PA, Zhu M, Ashjian P, De Ugarte DA, Huang JI, Mizuno H, Alfonso ZC, Fraser JK, Benhaim $\mathrm{P}$ and Hedrick $\mathrm{MH}$. Human adipose tissue is a source of multipotent stem cells. Mol Biol Cell. 2002; 13:4279-95. | Article | PubMed Abstract | PubMed FullText

46. Howell SM. The role of arthroscopy in treating osteoarthritis of the knee in the older patient. Orthopedics. 2010; 33:652. | Article | PubMed

47. Krych AJ, Bert JM and Levy BA. Treatment of OA of the knee in the middle-aged athlete: the role of arthroscopy. Sports Med Arthrosc. 2013; 21:23-30. | Article | PubMed

48. Hernigou P, Flouzat Lachaniette $\mathrm{CH}$, Delambre J, Zilber S, Duffiet $\mathrm{P}$, Chevallier $\mathrm{N}$ and Rouard $\mathrm{H}$. Biologic augmentation of rotator cuff repair with mesenchymal stem cells during arthroscopy improves healing and prevents further tears: a case-controlled study. Int Orthop. 2014; 38:1811-8. | Article | PubMed

49. Ministry of Health of the People's Republic of China. Guideline for transplantation and treatment with TE techniques (trial version). Beijing. 2009.
50. Childs JD and Piva SR. Psychometric properties of the functional rating index in patients with low back pain. Eur Spine J. 2005; 14:1008-12. | Article | PubMed

51. Bayar B, Bayar K, Yakut E and Yakut Y. Reliability and validity of the Functional Rating Index in older people with low back pain: preliminary report. Aging Clin Exp Res. 2004; 16:49-52. | Article | PubMed

52. Aust L, Devlin B, Foster SJ, Halvorsen YD, Hicok K, du Laney T, Sen A, Willingmyre GD and Gimble JM. Yield of human adipose-derived adult stem cells from liposuction aspirates. Cytotherapy. 2004; 6:7-14. | Article | PubMed

53. Szilvassy SJ. The biology of hematopoietic stem cells. Arch Med Res. 2003; 34:446-60. | Article | PubMed

54. Zuk PA, Zhu M, Mizuno H, Huang J, Futrell JW, Katz AJ, Benhaim P, Lorenz HP and Hedrick $\mathrm{MH}$. Multilineage cells from human adipose tissue: implications for cell-based therapies. Tissue Eng. 2001; 7:21128. | Article | PubMed

55. Halvorsen YD, Franklin D, Bond AL, Hitt DC, Auchter C, Boskey AL, Paschalis EP, Wilkison WO and Gimble JM. Extracellular matrix mineralization and osteoblast gene expression by human adipose tissue-derived stromal cells. Tissue Eng. 2001; 7:729-41. | Article | PubMed

56. Brzoska M, Geiger H, Gauer S and Baer P. Epithelial differentiation of human adipose tissue-derived adult stem cells. Biochem Biophys Res Commun. 2005; 330:142-50. | Article | PubMed

57. Du Y, Roh DS, Funderburgh ML, Mann MM, Marra KG, Rubin JP, Li $X$ and Funderburgh JL. Adipose-derived stem cells differentiate to keratocytes in vitro. Mol Vis. 2010; 16:2680-9. I Article I PubMed Abstract | PubMed FullText

58. Vossmerbaeumer U, Ohnesorge S, Kuehl S, Haapalahti M, Kluter $\mathrm{H}$, Jonas JB, Thierse $\mathrm{HJ}$ and Bieback K. Retinal pigment epithelial phenotype induced in human adipose tissue-derived mesenchymal stromal cells. Cytotherapy. 2009; 11:177-88. | Article | PubMed

59. Ferro F, Spelat R, Falini G, Gallelli A, D'Aurizio F, Puppato E, Pandolfi M, Beltrami AP, Cesselli D, Beltrami CA, Ambesi-Impiombato FS and Curcio F. Adipose tissue-derived stem cell in vitro differentiation in a threedimensional dental bud structure. Am J Pathol. 2011; 178:2299-310. | Article | PubMed Abstract | PubMed FullText

60. Li K, Han Q, Yan X, Liao L and Zhao RC. Not a process of simple vicariousness, the differentiation of human adipose-derived mesenchymal stem cells to renal tubular epithelial cells plays an important role in acute kidney injury repairing. Stem Cells Dev. 2010; 19:1267-75. | Article | PubMed

61. Seo MJ, Suh SY, Bae YC and Jung JS. Differentiation of human adipose stromal cells into hepatic lineage in vitro and in vivo. Biochem Biophys Res Commun. 2005; 328:258-64. I Article I PubMed

62. Banas A, Teratani T, Yamamoto Y, Tokuhara M, Takeshita F, Quinn G, Okochi $\mathrm{H}$ and Ochiya T. Adipose tissue-derived mesenchymal stem cells as a source of human hepatocytes. Hepatology. 2007; 46:219-28. | Article | PubMed

63. Aurich $H$, Sgodda $M$, Kaltwasser $P$, Vetter $M$, Weise $A$, Liehr T, Brulport M, Hengstler JG, Dollinger MM, Fleig WE and Christ B. Hepatocyte differentiation of mesenchymal stem cells from human adipose tissue in vitro promotes hepatic integration in vivo. Gut. 2009; 58:570-81. | Article | PubMed

64. Kim DH, Je CM, Sin JY and Jung JS. Effect of partial hepatectomy on in vivo engraftment after intravenous administration of human adipose tissue stromal cells in mouse. Microsurgery. 2003; 23:424-31. | Article | PubMed

65. Banas A, Teratani T, Yamamoto Y, Tokuhara M, Takeshita F, Osaki M, Kato $\mathrm{T}$, Okochi $\mathrm{H}$ and Ochiya T. Rapid hepatic fate specification of adipose-derived stem cells and their therapeutic potential for liver failure. J Gastroenterol Hepatol. 2009; 24:70-7. I Article I PubMed 
66. Chandra V, G S, Phadnis S, Nair PD and Bhonde RR. Generation of pancreatic hormone-expressing islet-like cell aggregates from murine adipose tissue-derived stem cells. Stem Cells. 2009; 27:1941-53. | Article | PubMed

67. Chandra V, Swetha G, Muthyala S, Jaiswal AK, Bellare JR, Nair PD and Bhonde RR. Islet-like cell aggregates generated from human adipose tissue derived stem cells ameliorate experimental diabetes in mice. PLoS One. 2011; 6:e20615. | Article | PubMed Abstract | PubMed FullText

68. Lin G, Wang G, Liu G, Yang LJ, Chang LJ, Lue TF and Lin CS. Treatment of type 1 diabetes with adipose tissue-derived stem cells expressing pancreatic duodenal homeobox 1. Stem Cells Dev. 2009; 18:1399-406. | Article | PubMed Abstract | PubMed FullText

69. Mizuno K, Muneta T, Morito T, Ichinose S, Koga H, Nimura A, Mochizuki $T$ and Sekiya I. Exogenous synovial stem cells adhere to defect of meniscus and differentiate into cartilage cells. J Med Dent Sci. 2008; 55:101-11. | Pdf | PubMed

70. Ong E, Chimutengwende-Gordon $\mathrm{M}$ and Khan W. Stem cell therapy for knee ligament, articular cartilage and meniscal injuries. Curr Stem Cell Res Ther. 2013; 8:422-8. | Article | PubMed

71. Horie M, Sekiya I, Muneta T, Ichinose S, Matsumoto K, Saito H, Murakami T and Kobayashi E. Intra-articular Injected synovial stem cells differentiate into meniscal cells directly and promote meniscal regeneration without mobilization to distant organs in rat massive meniscal defect. Stem Cells. 2009; 27:878-87. | Article | PubMed

72. Zellner J, Hierl K, Mueller M, Pfeifer C, Berner A, Dienstknecht T, Krutsch W, Geis S, Gehmert S, Kujat R, Dendorfer S, Prantl L, Nerlich $\mathrm{M}$ and Angele P. Stem cell-based tissue-engineering for treatment of meniscal tears in the avascular zone. J Biomed Mater Res B Appl Biomater. 2013; 101:1133-42. | Article | PubMed

73. Ruiz-Iban MA, Diaz-Heredia J, Garcia-Gomez I, Gonzalez-Lizan F, EliasMartin E and Abraira V. The effect of the addition of adipose-derived mesenchymal stem cells to a meniscal repair in the avascular zone: an experimental study in rabbits. Arthroscopy. 2011; 27:1688-96. | Article I PubMed

74. Coelho MB, Cabral JM and Karp JM. Intraoperative stem cell therapy. Annu Rev Biomed Eng. 2012; 14:325-49. | Article | PubMed Abstract | PubMed FullText

75. Salgado AJ, Reis RL, Sousa NJ and Gimble JM. Adipose tissue derived stem cells secretome: soluble factors and their roles in regenerative medicine. Curr Stem Cell Res Ther. 2010; 5:103-10. | Article | PubMed

76. Cai L, Johnstone BH, Cook TG, Tan J, Fishbein MC, Chen PS and March KL. IFATS collection: Human adipose tissue-derived stem cells induce angiogenesis and nerve sprouting following myocardial infarction, in conjunction with potent preservation of cardiac function. Stem Cells. 2009; 27:230-7. | Article | PubMed Abstract | PubMed FullText

77. Miyahara $Y$, Nagaya N, Kataoka M, Yanagawa B, Tanaka K, Hao H, Ishino K, Ishida H, Shimizu T, Kangawa K, Sano S, Okano T, Kitamura S and Mori $\mathrm{H}$. Monolayered mesenchymal stem cells repair scarred myocardium after myocardial infarction. Nat Med. 2006; 12:459-65. | Article | PubMed

78. Nakagami H, Maeda K, Morishita R, Iguchi S, Nishikawa T, Takami Y, Kikuchi Y, Saito Y, Tamai K, Ogihara T and Kaneda Y. Novel autologous cell therapy in ischemic limb disease through growth factor secretion by cultured adipose tissue-derived stromal cells. Arterioscler Thromb Vasc Biol. 2005; 25:2542-7. | Article | PubMed

79. Cai L, Johnstone BH, Cook TG, Liang Z, Traktuev D, Cornetta K, Ingram DA, Rosen ED and March KL. Suppression of hepatocyte growth factor production impairs the ability of adipose-derived stem cells to promote ischemic tissue revascularization. Stem Cells. 2007; 25:323443. | Article | PubMed

80. Kim JM, Lee ST, Chu K, Jung KH, Song EC, Kim SJ, Sinn DI, Kim JH, Park DK, Kang KM, Hyung Hong N, Park HK, Won CH, Kim KH, Kim M, Kun Lee
S and Roh JK. Systemic transplantation of human adipose stem cells attenuated cerebral inflammation and degeneration in a hemorrhagic stroke model. Brain Res. 2007; 1183:43-50. | Article | PubMed

81. Garcia MM, Fandel TM, Lin G, Shindel AW, Banie L, Lin CS and Lue TF. Treatment of erectile dysfunction in the obese type 2 diabetic ZDF rat with adipose tissue-derived stem cells. J Sex Med. 2010; 7:89-98. | Article | PubMed Abstract | PubMed FullText

82. Huang YC, Ning H, Shindel AW, Fandel TM, Lin G, Harraz AM, Lue TF and Lin CS. The effect of intracavernous injection of adipose tissue-derived stem cells on hyperlipidemia-associated erectile dysfunction in a rat model. J Sex Med. 2010; 7:1391-400. | Article | PubMed Abstract | PubMed FullText

83. Puissant B, Barreau C, Bourin P, Clavel C, Corre J, Bousquet C, Taureau C, Cousin B, Abbal M, Laharrague P, Penicaud L, Casteilla L and Blancher A. Immunomodulatory effect of human adipose tissue-derived adult stem cells: comparison with bone marrow mesenchymal stem cells. $\mathrm{Br}$ J Haematol. 2005; 129:118-29. | Article | PubMed

84. Yanez R, Lamana ML, Garcia-Castro J, Colmenero I, Ramirez M and Bueren JA. Adipose tissue-derived mesenchymal stem cells have in vivo immunosuppressive properties applicable for the control of the graft-versus-host disease. Stem Cells. 2006; 24:2582-91. | Article | PubMed

85. Niemeyer $\mathrm{P}$, Kornacker M, Mehlhorn A, Seckinger A, Vohrer J, Schmal $H$, Kasten P, Eckstein V, Sudkamp NP and Krause U. Comparison of immunological properties of bone marrow stromal cells and adipose tissue-derived stem cells before and after osteogenic differentiation in vitro. Tissue Eng. 2007; 13:111-21. | Article | PubMed

86. Cui L, Yin S, Liu W, Li N, Zhang W and Cao Y. Expanded adipose-derived stem cells suppress mixed lymphocyte reaction by secretion of prostaglandin E2. Tissue Eng. 2007; 13:1185-95. | Article | PubMed

87. DelaRosa O, Lombardo E, Beraza A, Mancheno-Corvo P, Ramirez C, Menta R, Rico L, Camarillo E, Garcia L, Abad JL, Trigueros C, Delgado M and Buscher D. Requirement of IFN-gamma-mediated indoleamine 2,3-dioxygenase expression in the modulation of lymphocyte proliferation by human adipose-derived stem cells. Tissue Eng Part A. 2009; 15:2795-806. | Article | PubMed

88. Yanez R, Oviedo A, Aldea M, Bueren JA and Lamana ML. Prostaglandin E2 plays a key role in the immunosuppressive properties of adipose and bone marrow tissue-derived mesenchymal stromal cells. Exp Cell Res. 2010; 316:3109-23. | Article | PubMed

89. Najar M, Raicevic G, Boufker HI, Fayyad-Kazan H, De Bruyn C, Meuleman N, Bron D, Toungouz M and Lagneaux L. Adipose-tissuederived and Wharton's jelly-derived mesenchymal stromal cells suppress lymphocyte responses by secreting leukemia inhibitory factor. Tissue Eng Part A. 2010; 16:3537-46. | Article | PubMed

90. Caplan Al and Dennis JE. Mesenchymal stem cells as trophic mediators. J Cell Biochem. 2006; 98:1076-84. | Article | PubMed

91. Zellner J, Mueller M, Berner A, Dienstknecht T, Kujat R, Nerlich M, Hennemann B, Koller M, Prantl L, Angele M and Angele P. Role of mesenchymal stem cells in tissue engineering of meniscus. J Biomed Mater Res A. 2010; 94:1150-61. | Article | PubMed

92. R. E. Marx. Platelet-rich plasma: evidence to support its use. Journal of Oral and Maxillofacial Surgery. 2004; 62:489-496.

93. Eppley BL, Pietrzak WS and Blanton M. Platelet-rich plasma: a review of biology and applications in plastic surgery. Plast Reconstr Surg. 2006; 118:147e-159e. | Article | PubMed

94. Mishra A and Pavelko T. Treatment of chronic elbow tendinosis with buffered platelet-rich plasma. Am J Sports Med. 2006; 34:1774-8. | Article | PubMed

95. Aspenberg $P$ and Virchenko O. Platelet concentrate injection improves Achilles tendon repair in rats. Acta Orthop Scand. 2004; 75:93-9. | Article | PubMed 
Nizar Al-Salahat, Stem Cell Biology and Research 2016,

http://www.hoajonline.com/journals/pdf/2054-717X-3-2.pdf

96. Anitua E, Andia I, Ardanza B, Nurden P and Nurden AT. Autologous platelets as a source of proteins for healing and tissue regeneration. Thromb Haemost. 2004; 91:4-15. | Article I PubMed

97. Hu Z, Peel SA, Ho SK, Sandor GK and Clokie CM. Platelet-rich plasma induces mRNA expression of VEGF and PDGF in rat bone marrow stromal cell differentiation. Oral Surg Oral Med Oral Pathol Oral Radiol Endod. 2009; 107:43-8. | Article | PubMed

98. Ishida K, Kuroda R, Miwa M, Tabata Y, Hokugo A, Kawamoto T, Sasaki $K$, Doita $M$ and Kurosaka $M$. The regenerative effects of platelet-rich plasma on meniscal cells in vitro and its in vivo application with biodegradable gelatin hydrogel. Tissue Eng. 2007; 13:1103-12. | Article | PubMed

99. Braun HJ, Wasterlain AS and Dragoo JL. The use of PRP in ligament and meniscal healing. Sports Med Arthrosc. 2013; 21:206-12. | Article | PubMed

100. Zhang J and Wang JH. Platelet-rich plasma releasate promotes differentiation of tendon stem cells into active tenocytes. Am J Sports Med. 2010; 38:2477-86. | Article | PubMed

101. Zhao SN, Liu WF and Zhang ZT. [Effect of platelet-rich plasma on cell proliferation and osteogenic activity of pulp stem cells]. Zhonghua Kou Qiang Yi Xue Za Zhi. 2013; 48:177-82. | Article | PubMed

102. Koh YG, Choi YJ, Kwon SK, Kim YS and Yeo JE. Clinical results and second-look arthroscopic findings after treatment with adiposederived stem cells for knee osteoarthritis. Knee Surg Sports Traumatol Arthrosc. 2015; 23:1308-16. | Article | PubMed

\section{Citation:}

Al-Salahat N. Pre-SVF arthroscopy: A case report of new concept of meniscus and cartilage regeneration using arthroscopy followed by intra-articular injection of adipose-derived stromal vascular fraction. Stem Cell Biol Res. 2016; 3:2.

http://dx.doi.org/10.7243/2054-717X-3-2 